\title{
18. PETROGRAPHY AND GEOCHEMISTRY OF VOLCANIC ASH LAYERS FROM LEG 87A, NANKAI TROUGH (SOUTH JAPAN) ${ }^{1}$
}

\author{
André Pouclet, Kantaro Fujioka, Jacques Charvet, and Jean-Paul Cadet ${ }^{2}$
}

\begin{abstract}
In the Leg 87A holes, 45 ash layers were sampled in Recent to upper Pliocene strata. The main volcanogenic deposits came from single eruptions or subcontemporaneous eruptions of cognate volcanoes. Some of them are mixed ashes produced from multiple eruptions and accumulated in reworked sediments. The petrographic and geochemical patterns indicate rhyolitic and dacitic compositions; andesitic glasses are scarce. We infer a magmatic affinity with calc-alkaline sources and a possible origin from the volcanic arc of southwestern Japan. A few samples may originate from the alkaline volcanism of southwestern Japan or the area south of Korea and the Sea of Japan.
\end{abstract}

\section{INTRODUCTION}

Leg $87 \mathrm{~A}$ was devoted to the study of subduction-related characteristics and processes operating in the Nankai Trough, off southwestern Japan. There, the trench fill is accreted and the large-scale geometry of the accretionary prism is well defined by the seismic profiles. Two drill sites were occupied (Fig. 1). Site 582 is located in the undeformed sediments filling the trench, about $2 \mathrm{~km}$ south of the deformation front (beginning of the protothrust zone); it offers a lithologic reference. Site 583 is located on the lowest structural terrace of the landward slope, at the toe of the basal thrust (Karig et al., 1983).

In the different holes drilled at both sites, several volcanic ash layers were crossed and sampled. This chapter reviews the results of the petrographic and geochemical study of those layers (Fig. 2).

\section{ASH LAYERS AT LEG 87A SITES}

\section{Site $\mathbf{5 8 2}$}

Two main lithologic units were recognized at Site 582 (Fig. 3). Unit 1 is approximately $560 \mathrm{~m}$ of trench-fill turbidites of the Recent to early Quaternary times. Unit 2, drilled from 566 to $749.4 \mathrm{~m}$ sub-bottom, consists of hemipelagic mud of the Shikoku Basin sequence of the early Pleistocene to late Pliocene times. Most likely, the approximate age at the base of the trench fill is about 0.86 Ma (site chapter, Site 582, this volume).

Volcanogenic sediment is common throughout the entire sequence and increases in the upper part of Unit 1 and in Unit 2, as reflected by the number of ash layers.

Unit 1 contains 13 ash layers, $1-25 \mathrm{~cm}$ thick. The two upper layers are the thickest (15-25 cm, Fig. 2). They include up to $25 \%$ of silt-size to sand-size glass shards ("bubble-wall" type and pumice type), generally colorless to pale brown. A shard content of 5 to $15 \%$, includ-

\footnotetext{
${ }^{1}$ Kagami, H., Karig, D. E., Coulbourn, W. T., et al., Init. Repts. DSDP, 87: Washington (U.S. Govt. Printing Office).

2 Addresses: (Pouclet) Département des Sciences de la Terre, Université d'Orléans, 45046 Orléans, Cedex, France; (Fujioka) Ocean Research Institute, University of Tokyo, Minamidai, Nakano-ku, Tokyo 164, Japan; (Charvet and Cadet) Département des Sciences de la Terre, Université d'Orleans, 45046 Orléans Cedex, France.
}

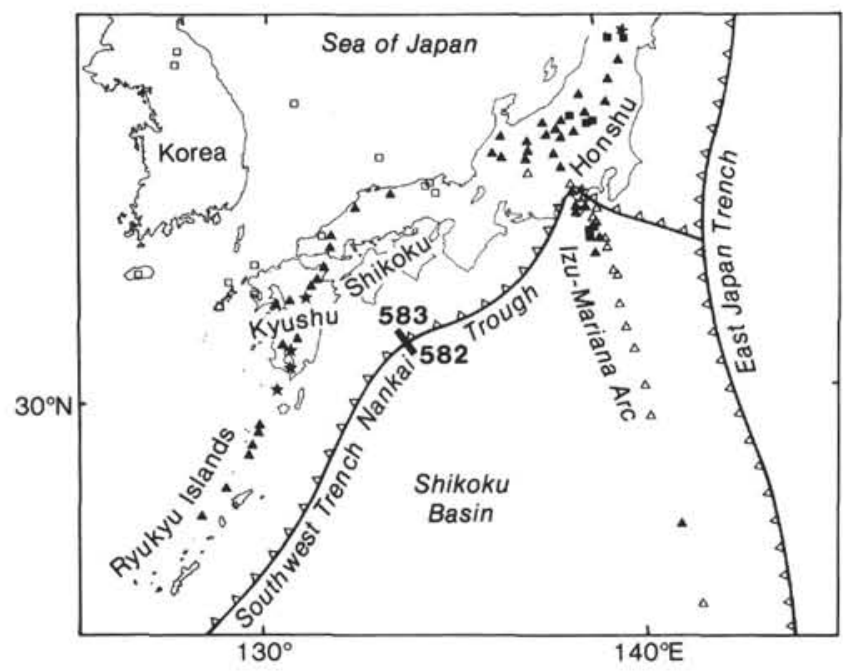

Figure 1. Geographic and structural setting of Leg 87A (Sites 582 and 583). Quaternary volcanoes and tectonic lines from Geological Atlas of Japan (Geological Survey of Japan, 1982). Open triangles = tholeiitic basalt; solid triangles $=$ andesites; solid squares $=$ dacite or rhyolite; open squares = alkaline rocks; stars = large explosive calderas.

ing micropumice and grains (lithic fragments) of volcanic glass and clastic-free minerals, is common in many other terrigenous layers. A concentration in the upper strata ( $0-20 \mathrm{~m}$ sub-bottom) may be late Pleistocene to Holocene (less than $0.21 \mathrm{Ma}$, according to biostratigraphic data). A second concentration, located above the middle of Unit 1 (220-230 m sub-bottom), is middle to early Pleistocene, below the $0.44-\mathrm{Ma}$ biostratigraphic marker.

Unit 2 contains 16 ash layers, $1-10 \mathrm{~cm}$ thick. They correspond to an important phase of early Quaternary volcanic activity.

\section{Holes 583B, 583C, and 583D}

Drilled just at the toe of the basal thrust, which was intercepted near $155 \mathrm{~m}$ sub-bottom (site chapter, Site 583, this volume), Hole 583B, 583C, and 583D contain sparse layers of dispersed ashes in hemipelagic muds and silts. Two upper Quaternary ash layers in Hole 583D (Fig. 2) occur above the thrust fault. 


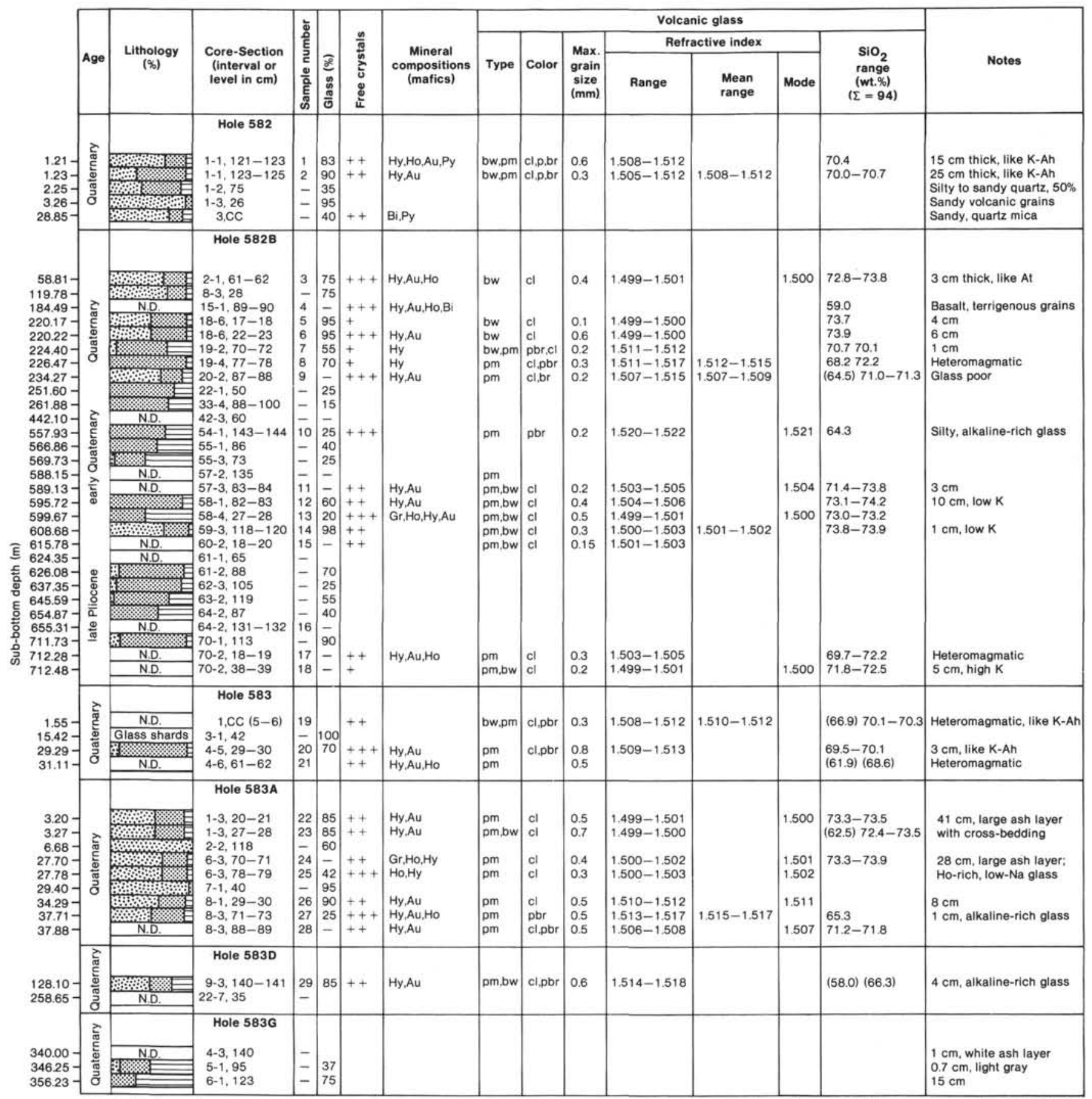

Note: In Lithology column, dots are sand, small dots are silt, and lines are clay (N.D. $=$ not determined). In Sample number column, dash indicates ash layer without chemical data. In Glass column, blank $=$ not determined, dash $=$ glass poor (not a tephra layer, but the glass shards were examined). In Free crystals column, $+=$ common, $++=$ abundant, $+++=$ very abundant. In Mineral compositions column, $\mathrm{Hy}=$ hypersthene, $\mathrm{Ho}=$ hornblende, $\mathrm{Au}=\mathrm{Augite}, \mathrm{Py}=\mathrm{pyrite}, \mathrm{Bi}=\mathrm{biotite}, \mathrm{Gr}=\mathrm{garnet}$. In $\mathrm{Type}$ column, $\mathrm{bw}=$ bubble-wall, $\mathrm{pm}=$ pumice. In Color column, $\mathrm{Cl}=$ colorless, $\mathrm{pbr}=$ pale brown, $\mathrm{br}=$ brown. $\mathrm{SiO}_{2}$ content in parentheses is the composition of a single analysis. In Notes column, K-Ah or AT refers to a kind of tephra layer $(K-A h=$ Kikai-Akahoya, AT $=$ Aira- $T n)$.

Figure 2. Petrographic characteristics of tephra layers, Leg 87A.

\section{Holes 583, 583E, 583F, and 583G}

These holes were drilled about $500 \mathrm{~m}$ farther landward than Holes 583B, 583C, and 583D. Three ash layers (3-5 cm thick) and many volcanic glass grains (10$15 \%$ ) are present in hemipelagic sandy mud of the upper part of this composite hole (upper Pleistocene). Layer 19 , in Core $583-1$ (Fig. 3), is located above the 0.21-Ma marker; its approximate age is 0.10 to $0.15 \mathrm{Ma}$, if we assume a sediment accumulation rate of $220 \mathrm{~m} / \mathrm{Ma}$ (deduced from the Hole 583A sequence and the lack of upper Quaternary sediments). Layers 20 and 21 , in Core $583-4$, should be dated at about $0.25 \mathrm{Ma}$, if a sediment accumulation rate of $330 \mathrm{~m} / \mathrm{Ma}$ is assumed. Three ash layers in the lower part (Hole 583G) may be lower Pleistocene. 


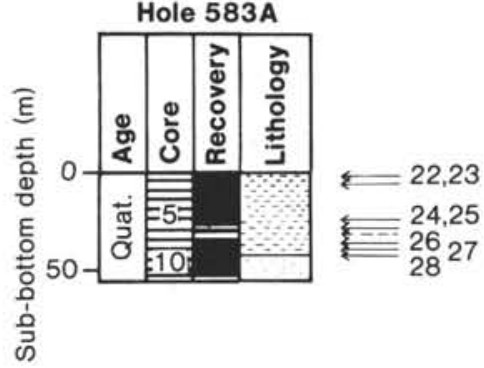

Hole 583G

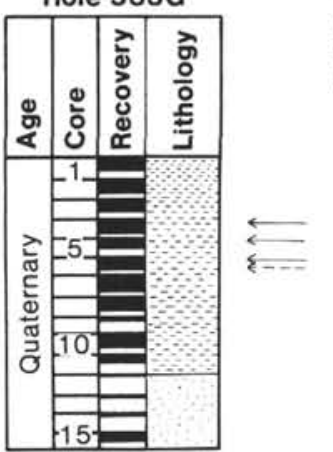

Slope deposits and

trench turbidites

Mud to silty sand

Hemipelagic mud
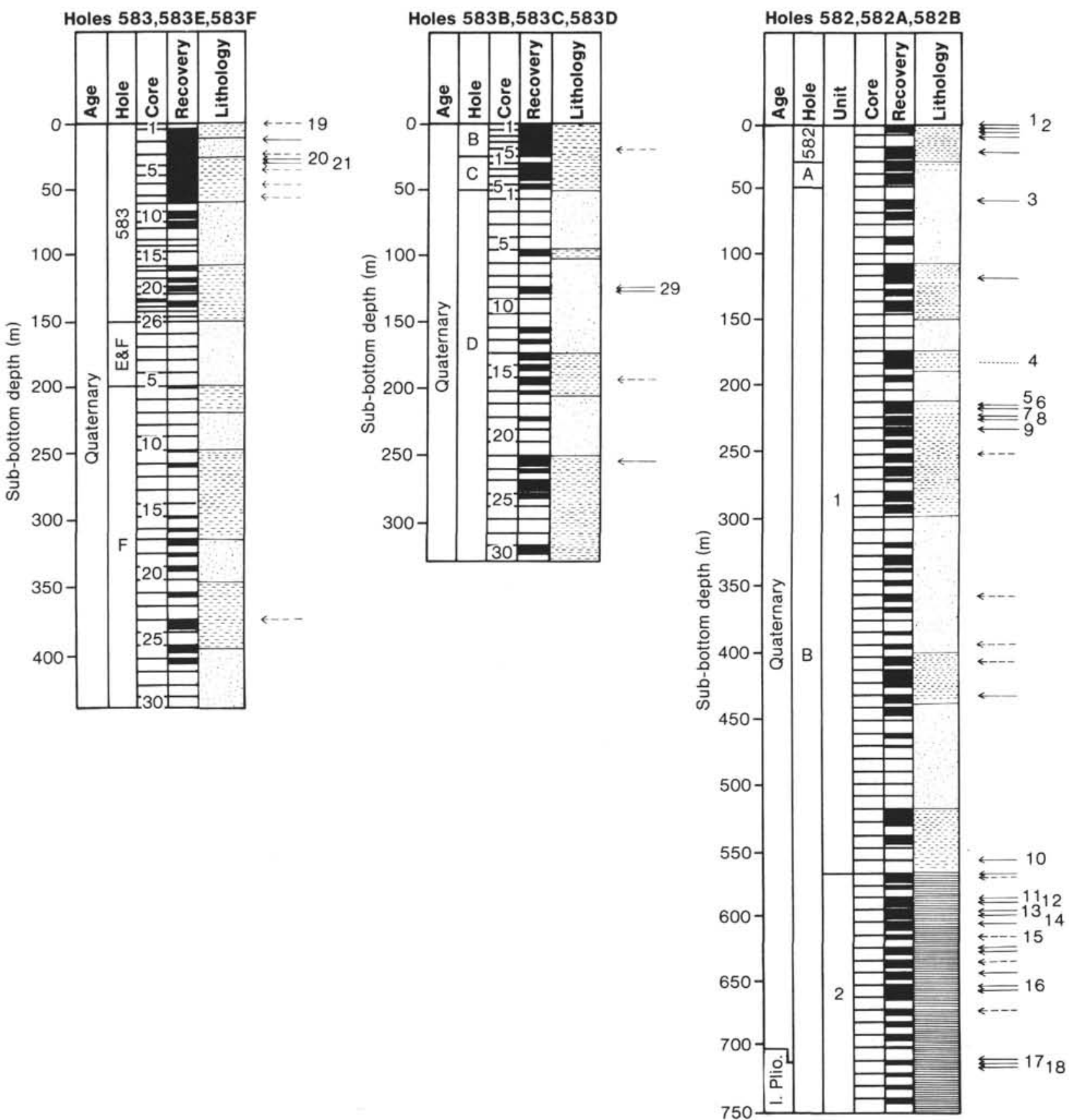

겅 
Table 1. Selected microprobe analyses (in wt. \%) of glass shards, Leg 87A.

\begin{tabular}{|c|c|c|c|c|c|c|c|c|c|c|c|c|c|c|c|c|}
\hline \multirow{4}{*}{$\begin{array}{l}\text { Hole } \\
\text { Core-Section } \\
\text { Interval in } \mathrm{cm} \\
\text { Our sample number }\end{array}$} & \multicolumn{2}{|c|}{582} & \multicolumn{14}{|c|}{$582 \mathrm{~B}$} \\
\hline & $1-1$ & $1-1$ & $2-1$ & $15-1$ & $15-1$ & $18-6$ & $18-6$ & $19-2$ & $19-4$ & $19-4$ & $20-2$ & $20-2$ & $54-1$ & $57-3$ & $58-1$ & $58-4$ \\
\hline & $121-123$ & $123-125$ & $61-62$ & $89-90$ & $89-90$ & $17-18$ & $22-23$ & $70-72$ & $77-78$ & $77-78$ & $87-88$ & $87-88$ & $143-144$ & $83-84$ & $82-83$ & $27-28$ \\
\hline & 1 & 2 & 3 & 4 & 4 & 5 & 6 & 7 & 8 & 8 & 9 & 9 & 10 & 11 & 12 & 13 \\
\hline $\mathrm{SiO}_{2}$ & 70.97 & 70.98 & 75.65 & 56.03 & 56.94 & 72.74 & 73.24 & 69.60 & 68.20 & 71.66 & 70.52 & 62.68 & 65.44 & 72.83 & 73.17 & 73.21 \\
\hline $\mathrm{TiO}_{2}$ & 0.54 & 0.56 & 0.11 & 1.46 & 0.95 & 0.25 & 0.26 & 0.40 & 0.50 & 0.17 & 0.40 & 0.72 & 0.65 & 0.32 & 0.36 & 0.20 \\
\hline $\mathrm{Al}_{2} \mathrm{O}_{3}$ & 12.44 & 12.64 & 11.99 & 14.46 & 19.62 & 11.18 & 11.26 & 12.41 & 13.13 & 12.12 & 12.19 & 14.53 & 14.64 & 11.90 & 10.85 & 11.69 \\
\hline$\Sigma \mathrm{FeO}$ & 2.28 & 2.50 & 1.17 & 10.55 & 6.63 & 1.04 & 0.92 & 2.03 & 2.29 & 1.32 & 1.76 & 2.30 & 3.27 & 1.24 & 1.08 & 0.94 \\
\hline $\mathrm{MnO}$ & 0.06 & 0.10 & 0.13 & 0.18 & 0.31 & 0.00 & 0.02 & 0.21 & 0.17 & 0.16 & 0.09 & 0.04 & 0.13 & 0.03 & 0.12 & 0.10 \\
\hline $\mathrm{MgO}$ & 0.44 & 0.43 & 0.13 & 3.80 & 1.10 & 0.18 & 0.20 & 0.43 & 0.51 & 0.14 & 0.30 & 0.88 & 0.62 & 0.33 & 0.27 & 0.21 \\
\hline $\mathrm{CaO}$ & 1.62 & 1.61 & 0.98 & 7.46 & 7.93 & 0.99 & 0.99 & 1.65 & 2.12 & 1.40 & 1.28 & 2.07 & 1.96 & 1.42 & 1.20 & 1.24 \\
\hline $\mathrm{Na}_{2} \mathrm{O}$ & 3.79 & 3.72 & 3.65 & 2.88 & 4.22 & 3.40 & 3.26 & 3.83 & 4.27 & 3.52 & 3.67 & 3.98 & 3.92 & 3.87 & 3.31 & 3.67 \\
\hline $\mathrm{K}_{2} \mathrm{O}$ & 2.64 & 2.80 & 3.05 & 0.65 & 0.80 & 2.99 & 2.95 & 2.69 & 2.44 & 2.79 & 2.70 & 4.07 & 5.01 & 2.66 & 2.31 & 2.95 \\
\hline $\mathrm{Cr}_{2} \mathrm{O}_{3}$ & 0.01 & 0.05 & 0.00 & 0.00 & 0.03 & 0.04 & 0.02 & 0.08 & 0.00 & 0.00 & 0.00 & 0.05 & 0.03 & 0.03 & 0.00 & 0.00 \\
\hline Total & 94.79 & 95.39 & 96.86 & 97.47 & 98.53 & 92.81 & 93.12 & 93.33 & 93.63 & 93.28 & 92.91 & 91.32 & 95.67 & 94.63 & 92.67 & 94.21 \\
\hline
\end{tabular}

\section{Hole 583A}

Located $400 \mathrm{~m}$ farther landward from Holes 583, 583E, $583 \mathrm{~F}$, and $583 \mathrm{G}$, this hole cut into the younger sediments, which were not present in other holes. In this sequence, the time marker of $0.21 \mathrm{Ma}$ is near the end of the hole, at $47 \mathrm{~m}$. Above it, seven ash layers (1-41 cm thick) are late Quaternary to Recent. A very large deposit (the youngest of this site) is in Core 1 (Plate 1). This last layer has an estimated age of 14,000 yr., if we assume a sediment accumulation rate of $220 \mathrm{~m} / \mathrm{Ma}$.

\section{GEOCHEMISTRY}

\section{Glass Analysis}

\section{Method}

Twenty-nine samples were geochemically investigated (ten major elements) using a Jeol (JCXA 733) electronprobe microanalyzer (EPMA) of the Ocean Research Institute (Tokyo University), with $15-\mathrm{kV}$ accelerating voltage, $20-\mu \mathrm{m}$ average defocused beam diameter, $0.01-\mu \mathrm{A}$ sample current, and 10-s count time. Ninety-seven analyses were performed on twenty-seven samples. (The analyses of Samples 15 and 16 were discarded because of technical failure.)

\section{Significance}

Table 1 gives the data from 34 analyses, including the most different compositions. The total amount of oxide components generally ranges from $92-96 \%$ (extremes: 91.32 and $98.53 \%$ ). The deficit is due to hydration of glass in seawater (Sheidegger et al., 1978). Ninkovitch (1979) demonstrates that hydration in glass shards reaches a saturation point of $4-5 \%$ in 250,000 to $400,000 \mathrm{yr}$. Our recent studies on samples from DSDP Legs 67 (Cadet et al., 1982) and 84 (Pouclet et al., 1985) show that hydration occurs more rapidly and leads to a greater content in acidic glass $(5-8 \%)$ than in basic glass $(3-5 \%)$. However, the initial water content is unknown, and magmatic acidic glasses may be richer in $\mathrm{H}_{2} \mathrm{O}$ ( $5 \%$ for rhyolitic glass in the Osaka group in Japan; Yoshikawa, 1978). Fujioka and others (1980) found a total ignition loss of near 6\% in an upper Pliocene acidic glass (DSDP Leg 57).

$\mathrm{SiO}_{2}$ content ranges from 56 to $75.6 \%$. Most analyses have dacitic to rhyolitic composition $\left(69<\mathrm{SiO}_{2}<74\right)$.
We analyzed many shards (5-15) from each ash layer. The composition is often homogenous (our Samples 3, $6,9,11,12,13,18,20,24,28$ ). (See Fig. 2 for DSDP designations of samples.) In the nomenclature of Huang (1980), they belong to type I, because they originated from single eruptions or subcontemporaneous eruptions of cognate volcanoes. Some layers are "heteromagmatic": Samples 8, 17, and 19 are dacitic and ryolitic; Sample 21 is andesitic and dacitic. Corresponding to type II, these are mixed ash from frequent, closely spaced eruptions originating from multiple or differentiated chambers, even within a single volcano. Alternatively, as in the case of Samples 22-23, the ash accumulated in reworked sediments (Plate 1).

\section{Magmatic Compositions}

Because of their alkali and silica contents (Fig. 4), volcanic glasses show a weak calc-alkalic to tholeiitic affinity. For the petrographic typology, because the magmatic composition is not water-free, the sum of the oxides is recalculated to $94 \%$, the average for acidic-glass analyses (Figs. 5, 6).

We registered 77 rhyolitic analyses, most of them having a medium $\mathrm{K}_{2} \mathrm{O}$ composition. The highest silica contents $\left(\mathrm{SiO}_{2}>75\right)$ occur in Samples 3 (582B-2-1, 61-62 $\mathrm{cm}), 22$ (583A-1-3, 20-21 cm), and 23 (583A-1-3, 27-28 $\mathrm{cm})$. One ash layer, Sample 18 (582B-70-2, 38-39 cm), has a higher potassium content. This sediment, from the upper Pliocene strata of the Nankai Trough site, is the oldest sampled. Otherwise, two lower Quaternary ash layers (Samples 12 [582-58-1, 82-83 cm] and 14 [582B$59-3,118-120 \mathrm{~cm}]$ ) have low $\mathrm{K}_{2} \mathrm{O}$ contents. Sample 24 (583A-6-3, 70-71 cm), a recent large ash layer, is classified as $\mathrm{Na}_{2} \mathrm{O}$-poor; however, it contains abundant free crystals of hornblende.

Twelve samples have a medium $\mathrm{K}_{2} \mathrm{O}$ dacitic composition.

Two analyses (linked dots, Figs. 4, 6) of Sample 4 (582B-15-1, 89-90 cm) indicate basaltic andesite of tholeiitic affinity; they consist of terrigenous grains in a dark gray sandy mud. One of them, with high $\mathrm{Al}_{2} \mathrm{O}_{3}$ and $\mathrm{Na}_{2} \mathrm{O}$ contents and low $\mathrm{FeO}$ and $\mathrm{MgO}$ contents, may be contaminated with microliths of labradorite (Fig. 4).

Six analyses of Samples 9, 10, 27 and 29 from Holes $582 \mathrm{~B}, 583 \mathrm{~A}$, and $583 \mathrm{D}$ show andesitic and dacitic specimens with very high $\mathrm{K}_{2} \mathrm{O}$ contents (crosses, Figs. 5, 6). 
Table 1. (Continued).

\begin{tabular}{|c|c|c|c|c|c|c|c|c|c|c|c|c|c|c|c|c|c|}
\hline \multicolumn{4}{|c|}{ 582B } & \multicolumn{2}{|c|}{$583 \mathrm{D}$} & \multicolumn{5}{|c|}{583} & \multicolumn{7}{|c|}{$583 \mathrm{~A}$} \\
\hline $59-3$ & $70-2$ & $70-2$ & $70-2$ & $9-3$ & $9-3$ & $1, \mathrm{CC}$ & $1, \mathrm{CC}$ & $4-5$ & 4-6 & $4-6$ & 1.3 & $1-3$ & $1-3$ & 6-3 & $8-3$ & $8-3$ & $8-3$ \\
\hline $118-120$ & $18-19$ & $18-19$ & $38-39$ & $140-141$ & $140-141$ & $5-6$ & $5-6$ & $29-30$ & $61-62$ & $61-62$ & $20-21$ & $27-28$ & $27-28$ & $70-71$ & $71-73$ & $71-73$ & $88-89$ \\
\hline 14 & 17 & 17 & 18 & 29 & 29 & 19 & 19 & 20 & 21 & 21 & 22 & 23 & 23 & 24 & 27 & 27 & 28 \\
\hline 72.81 & 69.20 & 72.09 & 71.93 & 56.46 & 66.12 & 67.39 & 71.16 & 69.59 & 63.48 & 69.15 & 75.42 & 64.59 & 74.11 & 73.10 & 66.42 & 68.14 & 72.17 \\
\hline 0.22 & 0.13 & 0.25 & 0.09 & 0.95 & 0.56 & 0.38 & 0.51 & 0.39 & 1.01 & 0.59 & 0.11 & 0.85 & 0.12 & 0.22 & 0.72 & 0.77 & 0.29 \\
\hline 11.07 & 14.29 & 12.88 & 11.94 & 14.78 & 14.23 & 15.02 & 12.61 & 12.90 & 16.21 & 13.23 & 11.80 & 14.77 & 11.89 & 11.25 & 14.74 & 15.12 & 12.02 \\
\hline 1.02 & 0.80 & 1.00 & 1.07 & 5.82 & 2.08 & 2.08 & 1.80 & 1.97 & 3.99 & 2.56 & 1.02 & 5.42 & 1.10 & 1.04 & 2.26 & 2.63 & 1.77 \\
\hline 0.07 & 0.10 & 0.13 & 0.07 & 0.22 & 0.10 & 0.13 & 0.05 & 0.09 & 0.09 & 0.10 & 0.06 & 0.11 & 0.11 & 0.00 & 0.06 & 0.11 & 0.10 \\
\hline 0.22 & 0.25 & 0.27 & 0.02 & 2.13 & 0.45 & 0.48 & 0.43 & 0.44 & 1.24 & 0.52 & 0.16 & 1.41 & 0.14 & 0.27 & 0.69 & 0.87 & 0.28 \\
\hline 1.31 & 1.75 & 1.23 & 0.58 & 4.44 & 1.27 & 3.19 & 1.87 & 1.60 & 4.97 & 2.38 & 1.13 & 4.29 & 0.97 & 1.39 & 1.80 & 1.92 & 1.37 \\
\hline 3.42 & 4.10 & 3.27 & 3.45 & 3.82 & 4.16 & 3.86 & 4.22 & 3.91 & 3.63 & 3.90 & 3.65 & 3.84 & 3.57 & 2.87 & 4.29 & 4.21 & 3.83 \\
\hline 2.40 & 2.74 & 2.80 & 4.59 & 2.83 & 4.62 & 2.18 & 2.66 & 2.66 & 1.80 & 2.40 & 3.28 & 1.87 & 3.16 & 2.91 & 4.62 & 4.31 & 2.94 \\
\hline 0.08 & 0.00 & 0.00 & 0.08 & 0.08 & 0.20 & 0.00 & 0.05 & 0.06 & 0.05 & 0.00 & 0.12 & 0.04 & 0.00 & 0.00 & 0.00 & 0.00 & 0.00 \\
\hline 92.62 & 93.36 & 93.92 & 93.82 & 91.53 & 93.79 & 94.71 & 95.36 & 93.61 & 96.47 & 94.83 & 96.75 & 97.19 & 95.17 & 93.05 & 95.60 & 98.08 & 94.77 \\
\hline
\end{tabular}

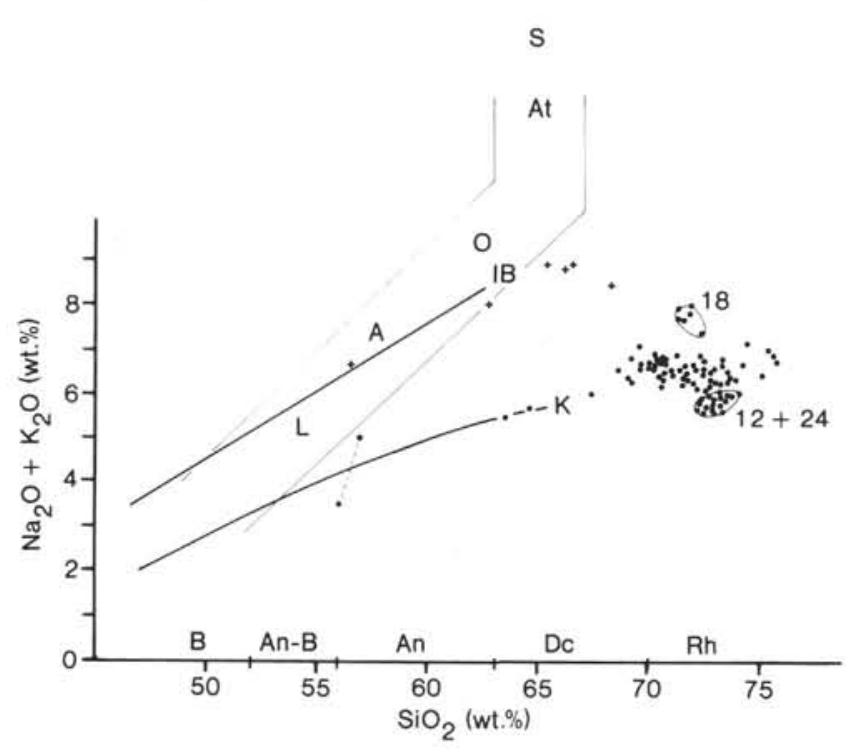

Figure 4. $\mathrm{SiO}_{2} /\left(\mathrm{Na}_{2} \mathrm{O}+\mathrm{K}_{2} \mathrm{O}\right)$ diagram, raw data. Dots represent tholeiitic to calc-alkaline glass compositions; crosses represent alkaline compositions. Area of feldspar compositions: $\mathrm{L}=$ labradorite, $\mathrm{A}$ $=$ andesine, $\mathrm{O}=$ oligoclase, $\mathrm{At}=$ anorthosite, $\mathrm{S}=$ sanidine. $\mathrm{IB}$ is the alkaline/subalkaline lava boundary (Irvine and Baragar, 1971) and $\mathrm{K}$, the calc-alkaline/tholeiitic lava boundary (Kuno, 1968). B locates basalt; An-B, basaltic andesite; An, andesite; Dc, dacite; $\mathrm{Rh}$, rhyolite. Sample 12 , low $\mathrm{K}_{2} \mathrm{O}$; Sample $18, \mathrm{~K}_{2} \mathrm{O}$ rich; Sample $24, \mathrm{Na}_{2} \mathrm{O}$ poor.

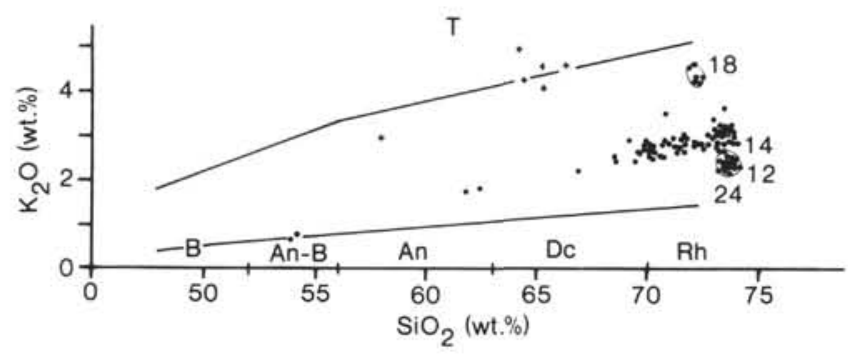

Figure 5. $\mathrm{SiO}_{2} / \mathrm{K}_{2} \mathrm{O}$ diagram, normalized sum to 94 . Symbol conventions as in Figure 4; T locates trachyte. Area limits are shown for medium-potassium and high-potassium lavas. Samples 12,18, and 24 as in Figure 4. Sample 14 is $\mathrm{K}_{2} \mathrm{O}$ poor.

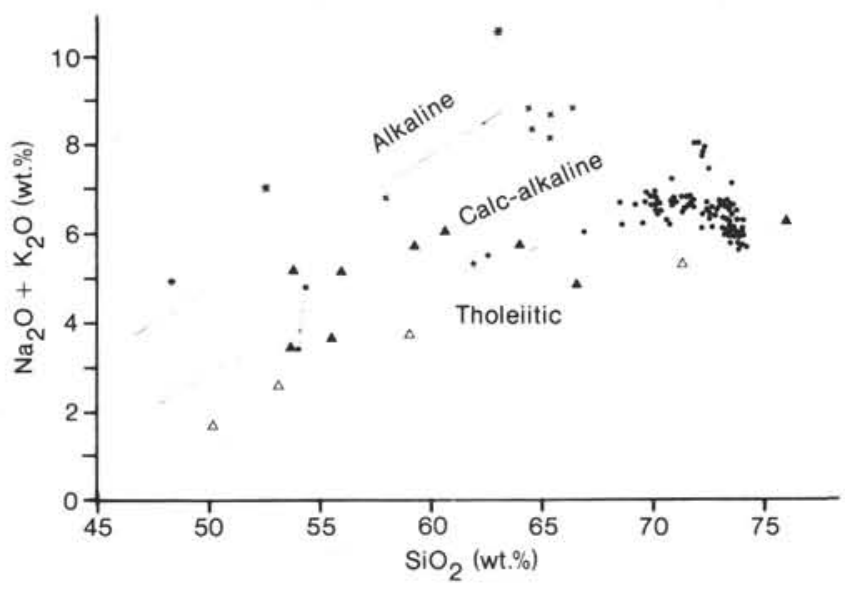

Figure 6. $\mathrm{SiO}_{2} /\left(\mathrm{Na}_{2} \mathrm{O}+\mathrm{K}_{2} \mathrm{O}\right)$ diagram, normalized sum to 94 . Data symbols and alkaline, calc-alkaline, and tholeiitic boundaries as in Figure 4. On-land data for comparison (table 23 of Isshiki, 1977, average chemical composition of aphyric volcanic rocks of Japan); open triangles $=$ the Izu-Hakone tholeiitic series, solid triangles $=$ the Izu-Hakone and southwestern Japan arc calc-alkaline series, and stars = the southwestern Japan alkaline series.

They may be calc-alkalic glasses containing andesine and oligoclase microliths or may belong to an alkaline magmatism (mugearite and trachyte); they are not too rich in $\mathrm{TiO}_{2}$.

Six samples $(6,7,13,22,27,28)$ were selected and analyzed for trace elements by the instrumental neutron activation (INA) method, together with 18 samples from Legs 57 and 87B (Fujioka et al., this volume). Sample 27 (583B-8-3, 71-73 cm) is very rich in Th, U, and hygromagmaphile-elements $(\mathrm{Rb}, \mathrm{Zr}, \mathrm{Cs}, \mathrm{La}, \mathrm{Hf}, \mathrm{Ta})$ and may be related to trachytic magma. The other samples are rich in these elements and have ratios indicating a calc-alkaline character.

\section{Comparison with On-Land Volcanism}

Glasses of rhyolitic to dacitic composition probably have their source in Kyushu, a region of large explosive acidic volcanism (Aso, Aira, Kikai), and in the Izu peninsula and islands (Fig. 1). Because the ash and pumice fall mainly spread eastward, the southwestern Japan volcanic arc is the most likely origin for aerial tephra. Detrital volcanic fragments dispersed in terrigenous layers 
(large pumice samples and basaltic or andesitic grains) may originate from the volcanic terrane of Izu, considering the southward axial transport of turbidite sediments of the trough (for example, Sample 4; see discussion in the site chapter, Site 582, this volume).

With regard to their major (and some minor) element chemistry, Leg 87A acidic glass shards may belong to the calc-alkaline series of southwestern Japan (Fig. 6). We are attempting correlations of tephra layers with onland volcanism, using mineralogic features, refractive index, and chemical analysis, following Machida's methods (1981). Some recent layers have the same characteristics as the widespread tephras found around the Japan Sea: Kikai-Akahoya, 6300 yr., and Aira-Tn, 21,00022,000 yr. (K-Ah and AT tephra-fall deposits; Machida and Arai, 1981). Samples 1 and 2 (582-1-1) and 19 (583$1, \mathrm{CC})$ may correlate with $\mathrm{K}-\mathrm{Ah}$, and Sample 3 (582B-2-1) with AT. Unfortunately, if we accept the biostratigraphic dates of these layers, these samples seem to be older than K-Ah and AT ash. The Recent and Holocene ash layer of Leg 87A, Core 583A-1 (our Samples 22-23), is heterogeneous (Plate 1) and includes some glass shards of AT-ash composition.

For trace elements determined from INA analyses, Samples $6,7,13,22$, and 28 belong to the calc-alkaline southwestern Japan arc, based on their Th and $\mathrm{K}$ contents (Sato and Sato, 1981). Sample 27, with its high hygromagmaphile-element content, should originate from alkaline volcanism of the southwestern Japan arc or south of Korea and the Sea of Japan.

Because of the very similar composition of volcanic products from this region, future accurate correlations of volcanic products and ash layers require further development of analytical techniques like INA (cf., Rose et al., 1982) and more precise dating of ash layers.

\section{CONCLUSION}

The ash layers deposited off southwestern Japan (Nankai Trough area) denote explosive activity from the late Pliocene to early Quaternary, middle Quaternary, and late Pleistocene to Recent.

Glasses are mainly acidic with a weak calc-alkaline affinity and a medium $\mathrm{K}_{2} \mathrm{O}$ content. Characterization of a few layers is possible. As a whole, they belong to the southwestern Japan arc, but some alkaline products may also originate from south of the Sea of Japan.

The sparse core coverage and the lack of recovery of upper Quaternary strata do not allow accurate correlation of these sites with recent widespread tephra horizons.

\section{ACKNOWLEDGMENTS}

We would like to acknowledge Dr. W. Coulbourn and Ms. J. Blakeslee for their very useful comments and their corrections of the manuscript.

\section{REFERENCES}

Cadet, J. P., Pouclet, A., Thisse, Y., Bardintzeff, J. M., and Azéma, J., 1982. Middle America Neogene explosive volcanism and ash layers: evidence from the Middle America Trench transect, Deep Sea Drilling Project Leg 67. In Aubouin, J., von Huene, R., et al., Init. Repts. DSDP, 67: Washington (U.S. Govt. Printing Office), 475-491.

Fujioka, K., Furuta, T., and Arai, F., 1980. Petrography and geochemistry of volcanic glass: Leg 57, Deep Sea Drilling Project. In Scientific Party, Init. Repts. DSDP, 56, 57, Pt. 2: Washington (U.S. Govt. Printing Office), 1049-1066.

Geological Survey of Japan, 1982. Geological Atlas of Japan: Tokyo (Kokuko Map Company, Ltd), pp. 1,68.

Huang, T. C., 1980. A volcanic sedimentation model: implications of processes and responses of deep-sea ashes. Mar. Geol., 38: $103-122$.

Irvine, T. N., and Baragar, W. R. A., 1971. A guide to the chemical classification of the common volcanic rocks. Can. J. Earth. Sci., $8: 523-548$.

Isshiki, N., 1977. Petrographic provinces and major element chemistry. In Tanaka, K., and Nozawa, T., (Eds.), Geology and Mineral Resources of Japan (Vol. 1, 3rd ed.): Tsukuba (Geol. Surv. Jpn.), 397-402.

Karig, D. E., Kagami, H., and DSDP Leg 87 Scientific Party, 1983. Varied responses to subduction in Nankai Trough and Japan Trench forearcs. Nature, 304(5922):148-151.

Kuno, H., 1968. Differentiation of basalt magmas. In Hess, H. H. and Poldervaart, A. (Eds.), Basalts (Vol. 2):New York (Interscience, Wiley), 623-688.

Machida, H., 1981. Tephrochronology and Quaternary studies in Japan. In Self, S., and Sparks, R. S. J. (Eds.), Tephra Studies: Holland (D. Riedel Publ. Co.), pp. 161-191.

Machida, H., and Arai, F., 1981. Late Quaternary large eruptions recorded in distal areas around Japan. IAVCEI Symposium Arc Volcanism, Volcanol. Soc. Jpn. and Int. Assoc. Volcanol. Chem. Earth's Inter., pp. 214-215. (Abstract)

Ninkovitch, D., 1979. Distribution, age and chemical composition of tephra layers in deep-sea sediments off western Indonesia. J. Volcanol. Geotherm. Res., 5:67-86.

Pouclet, A., Cadet, J. P., Fujioka, K., and Bourgois, J., 1985. Ash layers from Deep Sea Drilling Project Leg 84: Middle America Trench Transect. In von Huene, R., Aubouin, J., et al., Init. Repts. DSDP, 84: Washington (U.S. Govt. Printing Office), 609-618.

Rose, W. I., Jr., Bornhorst, T. J., and Drexler, J. W., 1982. Preliminary correlation of Quaternary volcanic ashes from the Middle America Trench off Guatemala, Deep Sea Drilling Project Leg 67. In Aubouin, J., von Huene, R., et al., Init. Repts. DSDP, 67: Washington (U.S. Govt. Printing Office), 493-495.

Sato, K., and Sato, J., 1981. U- and Th-series radioactivity ratio and $\mathrm{K}$ content in volcanic rocks occurring along volcanic fronts of Japan. LAVCEI Symposium Arc Volcanism, Volcanol. Soc. Jpn. and Int. Assoc. Volcanol. Chem. Earth's Inter., pp. 320-321. (Abstract)

Sheidegger, K. F., Jezek, P. A., and Ninkovitch, D., 1978. Chemical and optical studies of glass shards in Pleistocene and Pliocene ash layers from DSDP Site 192, northwestern Pacific Ocean. J. Volcanol. Geotherm. Res., 4:99-116.

Yoshikawa, S., 1978. Chemical compositions of glass in volcanic ash layers of the Osaka Group. J. Geol. Soc. Jpn., 84:131-140.

Date of Initial Receipt: 25 July 1984

Date of Acceptance: 8 February 1985 
PETROGRAPHY AND GEOCHEMISTRY, VOLCANIC ASH LAYERS, LEG 87A

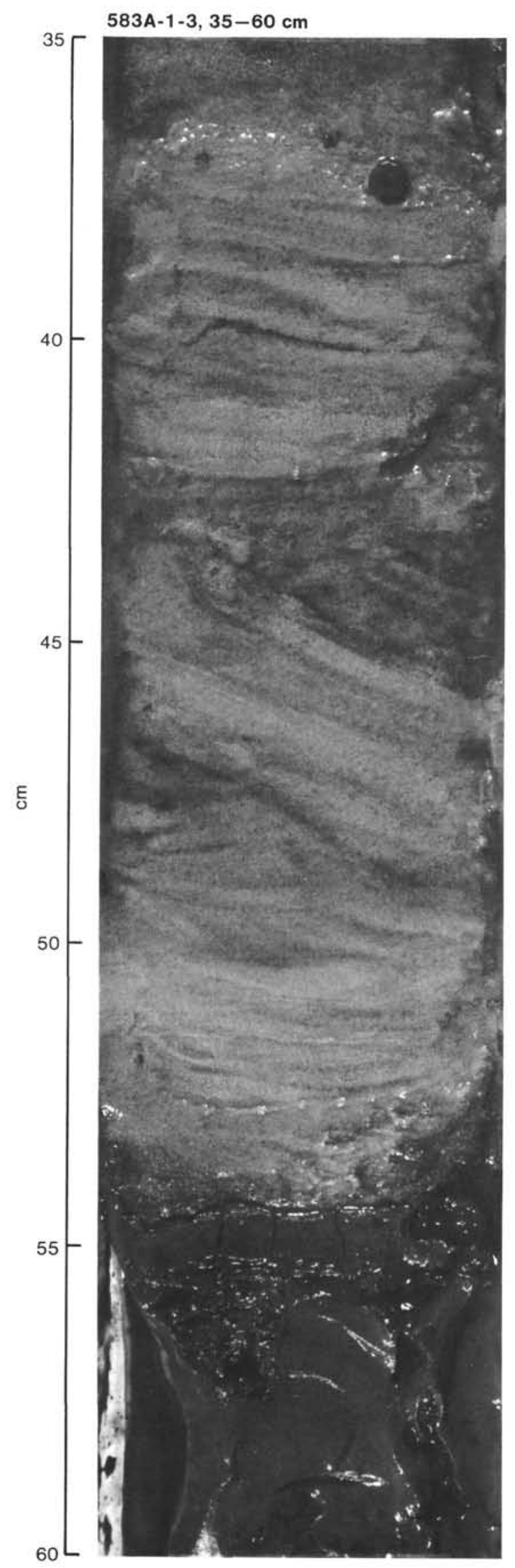

Plate 1. Lower part of the $41 \mathrm{~cm}$ ash layer in Core 583A-1 (Samples 22-23). Note graded bedding and sedimentary rework. 